\title{
Space Syntax in an idiorrhythmical conglomerate: the case of Jardim Piratininga, São Paulo, Brazil
}

\section{Luciano Abbamonte da Silva, Heraldo Ferreira Borges, Bruno Futema}

Mackenzie Presbyterian University, São Paulo, SP, Brazil

E-mail: lucianoabbamonte.silva@mackenzie.br, heraldo.borges@mackenzie.br, bruno. futema93@gmail.com

\begin{abstract}
This article aims to contribute to urban design alternatives in the Jardim Piratininga neighborhood and to offer subsidies for future Urban Intervention Projects (PIU).This area, located in the East Zone of the Municipality of São Paulo, was defined by the 2012 Strategic Master Plan as Special Zone of Social Interest - ZEIS. It is presumed that the studied area, considered as an emerging urban fabric stratum that lacks in a large part of basic urbanization infrastructures, holds in itself the potential for a future readaptation and complementation of its roadway. The methodology that will be used in this analytical approach of the urban form, known as Space Syntax, seeks to provide: support for decision making; tools to calibrate these decisions; evaluate proposed scenarios; as well as combining other methods and tools. This methodology enables to confirm something we probably already know the need to complete 'mesh design' in contemporary cities urbanized areas that have a diverse constitution from that ones observed in more sedimented and stable fields (consolidated city). As a result of the research done for this article, there will be presented some possibilities of transformation of the neighborhood roadway according to diverse scenarios, but based on the dynamics of the place itself, and also with the surrounding urban fabric.
\end{abstract}

Keywords: Space Syntax, idhiorrhythmical conglomerate, Jardim Piratininga, Urban Intervention Project, scenarios.

\section{Introduction}

This article is the result of a partnership between the Research Group called Urban Issues: Design, Architecture, Planning and Landscape - Q.URB, and the Group of Studies of the Urban Form in Brazil - FU.bá, both based at The Faculty of Architecture and Urbanism of Mackenzie Presbyterian University. It is also an extension, in Brazilian lands, of a workshop conducted by the Lusophone Network of Urban Morphology - PNUM, at the Faculty of Engineering of the University of Porto, in 2015. We are dear to the concepts, methodologies and theoretical references contained in the derived e-book, which was published with the results of this research work (OLIVEIRA, MONTEIRO, 2015). More specifically, we find it unnecessary to make introductions or major theoretical insights into Space Syntax and its vast field of practical experimentation and theoretical refinement: we consider this basic bibliography and ongoing research, from the seminal text published by Hillier and Leaman in 1976, The classic Space is the Machine of 1996, until arriving at contemporary researchers that produces in Portuguese language, as Medeiros (2006) and Viana (2015).

For this particular article, we accomplished 
a exercise using space syntax concepts whose development resulted in a restricted but sharp local analysis. We dare to say that the approach in which this task was performed implies observing, reflecting, analyzing and acting in an area of infrastructural enclaves, precarious settlements, environmental fragility and social vulnerability, in the complex context of a contemporary metropolis like São Paulo. In this context, we consider the idea of metropolis as a problematic and imprecise concept, but which designates a global condition that can be identified in local sphere situations, as discussed in David Cunningham's The Concept of Metropolis (2005).

Considering this scenario, the case of Jardim Piratininga, located in the East Zone of the Municipality of São Paulo, is emblematic, since it is an area circumscribed by notable physical barriers: highway, railroad, circumvallation stream and a large industrial plant deactivated. Those are the elements that structure this portion of urban fabric and that give peculiarity to this portion of territory (Figure 1). The only reasonable way to overcome the obstacles represented in the image that are the only exclusive access routes to the consolidated urban fabric, are two small tunnels that cross the railroad. They are short enough not to allow a fire truck to go through in case of causality, for example (Figure 2). Other prominent

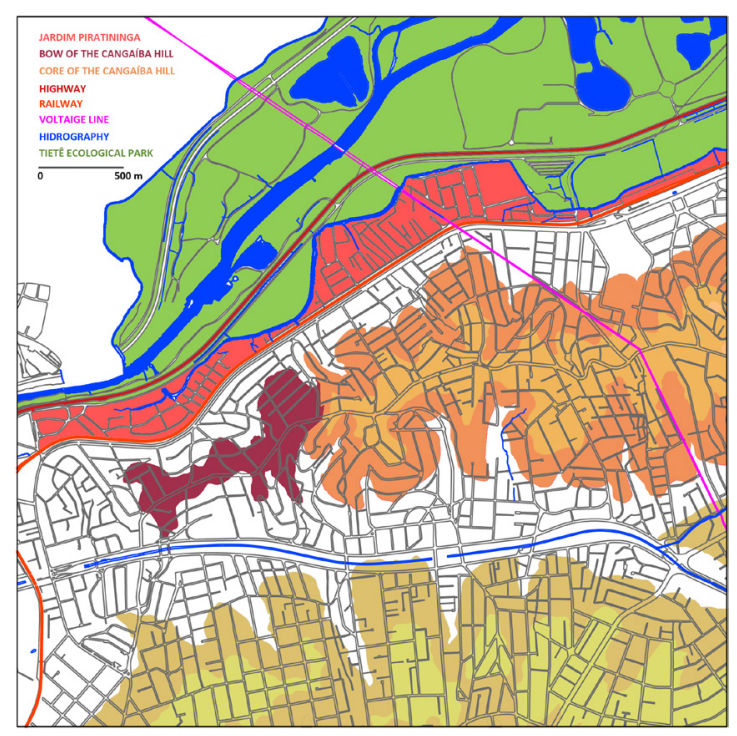

Figure 1. Set of Analysis (authors, 2017)

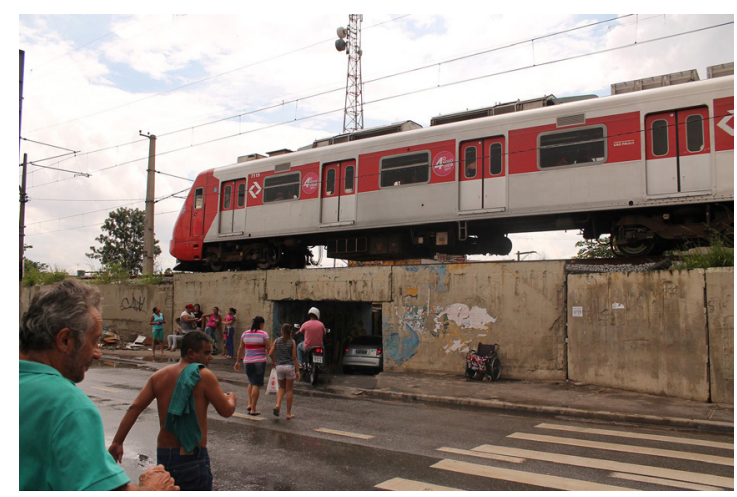

Figure 2. Wormhole: the tunnel that crosses the railroad (Leonardo Gobbi, 2016)

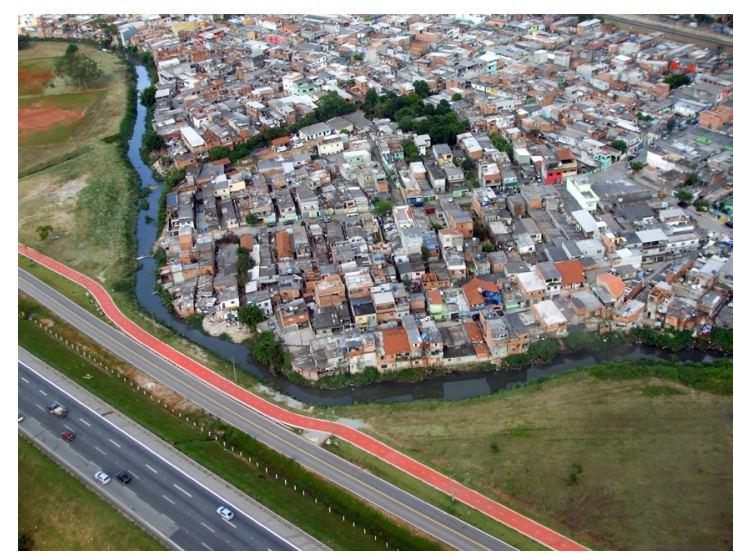

Figure 3. A tree mass in a stream mouth (Municipal Housing Department, 2016)

elements in this article analyzed landscape are: a tree mass in a stream mouth (Figure $3)$; the Cangaíba Hill; the valley bottom roads denominated Assis Ribeiro Avenue and Governador Carvalho Pinto Avenue; and the electric transmission line.

The tunnels of Jardim Piratininga are like an "wormhole": a dimensional crevice that leads passersby, when crossing it, to a completely different destination from the place of origin. That's why we consider Jardim Piratininga as an idiorrhythmic conglomerate endowed with its own rhythm, a conceptual figure proposed by Paola Viganò to address the reflection, description and analysis of contemporary urban phenomena. The term is also referenced in Roland Barthes work, in which the author analyses the very urban condition of how to live together. Such phenomena, defined by Viganò 
as a sort of phantom of the epoch, a "widespread uneasiness" in the face of its complex and banal condition, would be endowed with the character of porosity, and therein would the difficulty of defining its condition lie:

Porosity refers to density, distance, to taking into account elements of ecological racionality, but it also has deep social implications. In the broadest sense, the phantom is perturbed by reflections that concern the sustainability of our acts, of projects and decisions; a complex theme, dense with ambiguity, that simultaneously deals with ecological, social and economic questions. Beyond all rhetoric, sustainability is still considered a radical choice for a project, for a prosecutor, an inhabitant; for a city and a territory (2006, p. 336).

At this point, we have already found a fundamental intersection between the expression proposed by Paola Viganò to address the contemporary urban phenomena - porosities - and the Space Syntax theory, enunciated by Bill Hillier: the urban form as a result of a series of decisions, which can be complex or antagonistic to one another, but which reveals, as material evidence of an urban form, the very substratum of the human condition that takes place there. It also brings the notion of sustainability and/or resilience closer to any decision to be taken in terms of urban fabric transformation, considering that even local interventions may have a reflection on metropolitan dynamics. Conversely, metropolitan interventions may reduce or increase drastically the integration conditions of local fabrics ${ }^{1}$.

Based on these theoretical references, we sought to contribute to urban design alternatives in the Jardim Piratininga neighborhood, and to offer subsidies for future Urban Intervention Projects (in portuguese, PIU), since this area was defined by the 2012 Strategic Master Plan as a Special Zones of Social Interest (in portuguese, ZEIS). It is assumed that the studied area, considered as an emerging urban fabric stratum that lacks of basic urbanization infrastructures, holds in itself the potential for a future re-adaptation and complementation of its roadway.
This exercise image results are opportune, since many areas of metropolitan borders, constituted by precarious and/or irregular settlements, lack either a planialtimetric survey in their totality, or an update of the existing cartographic bases. In the case of Jardim Piratininga, until the beginning of 2016, only some most consolidated part of the urban layout was on the bases of the City Hall, and there were no surveys of thousands existing buildings. Thanks to the work of the Urban Issues Group of Research (Q.URB), carried out with public agencies in conjunction with the residents' neighborhood association (Claro et all, 2016), the Municipal Housing Department provided an updated and detailed planialtimetric survey of the entire area, thus enabling the necessary basic documents for territory analysis with the space syntax tool.

\section{Methodology}

The first step of the analysis consisted in drawing the axial map of the area, with dimensions of $3.50 \times 2.75$ kilometers, a spatial cut that was based on relevant elements of the urban structure, considering a minimum reference diameter of 2 kilometers from the object of study. The axial map consists of the smallest set of the largest observable lines walkable by pedestrians, defining convex spaces and their connections. It is interesting to note the presence of staircases, alleys, alleys, tunnels, walkways and even unpaved tracks in the area. These urban elements guarantee, in the absence of larger infrastructure, a certain capillarity to local fabrics.

The second step of the analysis was based in the use of the DepthmapX-0.30, a software used to generate the performance samples of the existing urban shape, according to the determined internal parameters, which were: Connectivity; Choice; Mean Depth; Global Integration $[\mathrm{HH}]$; Local Integration (R9); Synergy - Total Integration [HH] R9 R9. In sequence, this procedure was repeated in order to establish four hypothetical transformations of the urban form, ranging from more subtle interventions to a more radical situation, with two large interventions. The third step of the analysis has considered comparisons among 
the samples of the same parameter, verifying which are the constants and the variables according to the four hypotheses proposed.

\section{Measurement and analysis}

In general, the existing situation revealed that the Jardim Piratininga is, globally and locally, less integrated than the other local fabrics of the analyzed set. It means that the constituent spaces of Piratininga are less close and less accessible than the others with which it relates, in the whole of the urban fabric in which it is inserted. It also has spaces less connected to others and, in addition, it has the segments with a greater mean depth.

In the existing set, the local fabrics that stand out with greater synergy are the "bow" of the Cangaíba Hill, as well as its two valley bottom roads that surround it, Governador Carvalho Pinto Avenue and Assis Ribeiro Avenue. Other outstanding elements are the hillsides bridging the relief, as Puruá Street, Bartolomeu Cadres Street and Coronel Meireles Street. In Jardim Piratininga, Adelina Linhares Street, the one with the tunnel and that shelters the street market-place on Saturday, stands out as the main transverse axis of Jardim Piratininga, making direct connection with the consolidated fabric. And, in the longitudinal direction, Olga Artacho Street, where several elongated and stretched streets connect (Figure 4).

Conversely, in the whole of the that urban woof, the crust of the Cangaíba hill also presents a greater branching and fragmentation, showing local fabrics more spatially segregated and similar, in degree, with Jardim Piratininga. However, while the crust of the hill has a more constant pattern, formed by the intersection of broken lines, the Jardim Piratininga, a flat area of lowland, consists of more heterogeneous tracings. This situation is ironic because it reveals a mode of construction that has made

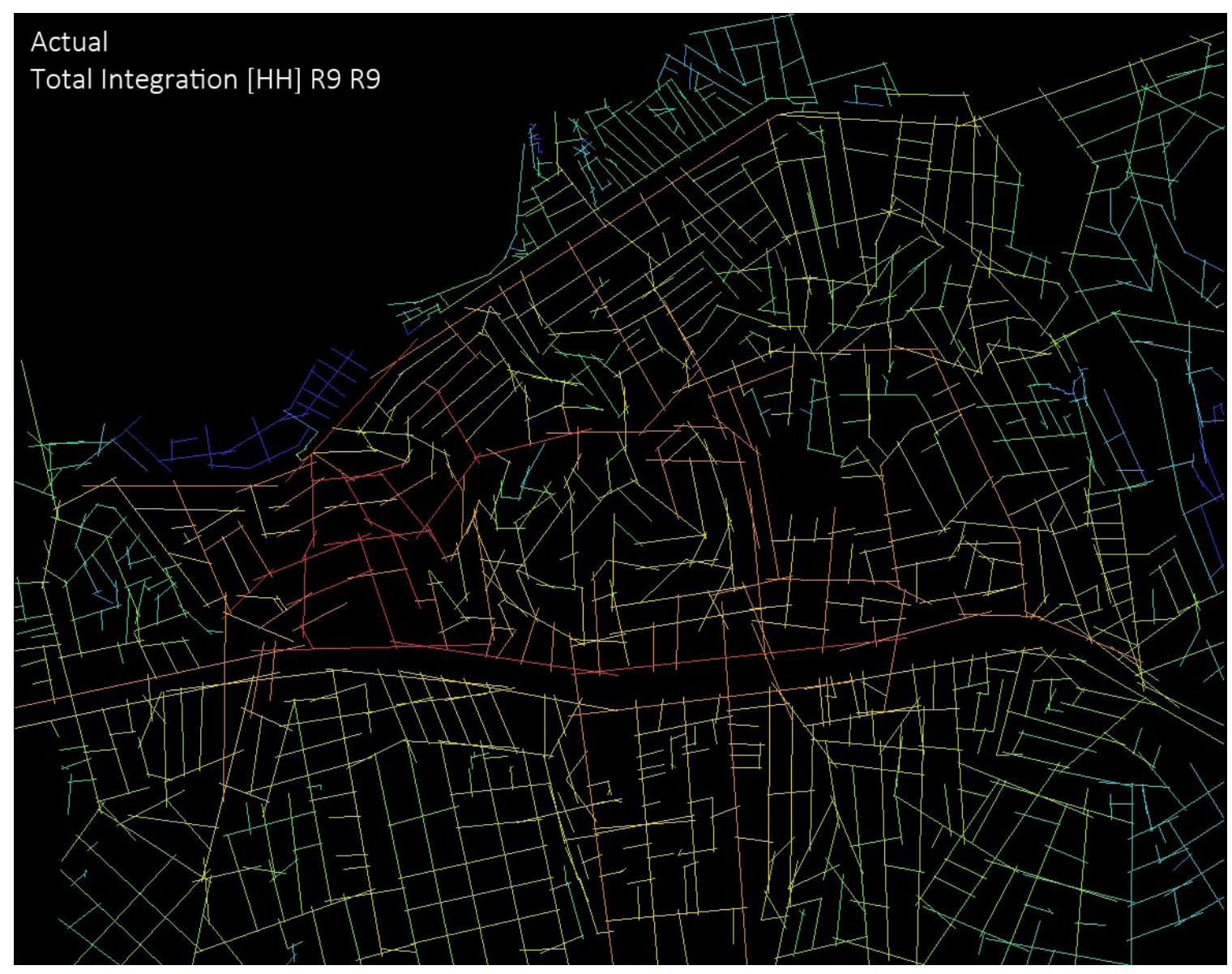

Figure 4. Existent Situation: Total Integration [HH] R9 R9 (authors, 2017) 
it impossible to standardize more regular grids, even in flat zones.

The hypothesis 1 , defined as a minimal, punctual intervention, considered a link between Jardim Piratininga and Vila do Sapo, to the East, two isolated neighborhoods due to the presence of a large urban void: an abandoned industrial lot, like so many others that are located along the railway. This lot is the object of urban and social housing projects, but there is still no clear definition regarding its effective transformation. We believe that a connection on the ground floor level is fundamental to a greater flow capacity for the Jardim Piratininga and a consequent supply of basic urban services, factually limited by the small section of the existing tunnels. However, the analysis from the space syntax, has revealed that this kind of connection would not affect the the global and local integration of Jardim Piratininga, rather than the synergy of Vila do Sapo, the actually most segregated local fabric of the whole.

The hypothesis 2, defined as a minimal intervention, although more comprehensive, consisted in complementing the route of the border road along the circumvallation stream, as well as punctual connections in some of the several dead ends of Jardim Piratininga routes, thus increasing the permeability of its layout. It was also proposed, based on this trajectory, the requalification of the stream mouth that constitutes the most significant tree mass of the entire area. Hence, in the same way as hypothesis 1, the modifications proposed in the layout do not modify the condition of integration, although, with a greater regularity of the tracing. We have perceived a subtle increase in the levels of integration, tending to the middle, as well as a greater regularity between its parts.

It should be said that, regarding hypotheses 1 and 2 , even if they are more modest interventions compared to what can be imagined and proposed, they are not new propositions but long considered ones. This case demonstrates that, in the case of São Paulo, a contemporary metropolis, the question of idiorrhythmic conglomerates is related to the absence or insufficiency of large works that contemplate and reduce spacial segregation that characterizes this type of situation.
Based on this last quote, hypothesis 3 proposes a more radical intervention: the reconversion of electric transmission lines and towers, a specific metropolitan infraestructure which, through hills and other obstacles, make up straight fissures and barriers in the territory. Even though this approach is not new, it's important to remember that metropolitan energy supply is guaranteed at the expense of physical barriers and fragmentation of local fabrics and that, however, such a constraint can also become an opportunity to provide architecture infraestructures to the metropolitan areas, paraphrasing Alberto Varas.

It is worth mentioning that usually the axes designed by eletric infraestrutures have mandatory side deflections, defined by law and that their dimensions vary according to the electric charge capacity, which retreats as a safety measure as well as public health. But such limits are rarely respected, and what is observed is all manner of subversion of the norm, from occupations existing on the edges of the axis, as well as circumscribed and below (Figure 5). So, what Hypotesis 3 proposes is the reconversion of this infrastructure by burying all electrical wiring, a large and heavy work that would allow the creation of a new road axis and could even be thought from infraestruture modalities that priorizes light vehicles on rails and bicycle paths. Here, it is not a matter of discussing the cost of these measures, but rather that they respond, as hypotheses, to demands both local and global. Hypothesis 3 also considered a direct link

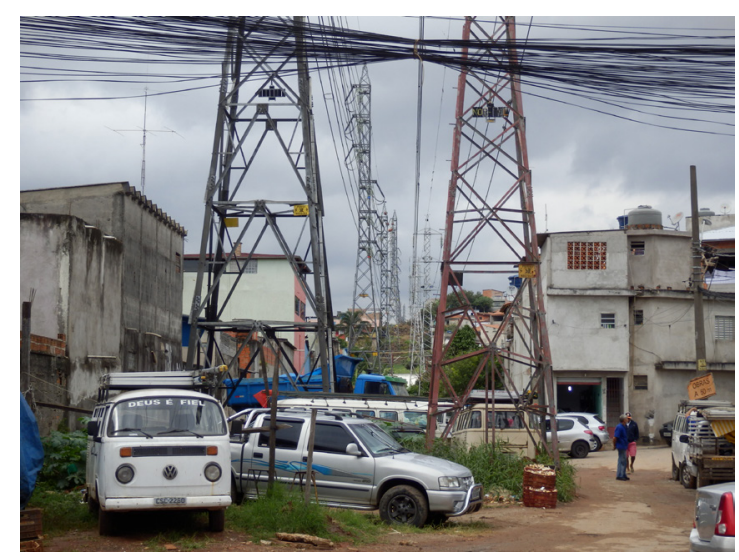

Figure 5. Deviation from the rule: the high voltage line (Aya Saito, 2015) 
crossing the railroad, which would imply in some work of transposition, or catwalk, or viaduct or tunnel. We know that this kind of work, being intervention after an existing situation, implies a greater degree of complexity, including the character of the metropolitan infrastructures, more specifically the railroad. However, we understand that it is feasible, especially in segments that are already made up of curves, the implementation of a second extension as a line segment that would not compromise the flow of the system, even if it implies, locally, in works of considerable size.

Hypothesis 3 confirmed, albeit partially, a suspicion: that a transverse axis of metropolitan character would increase the integration of Jardim Piratininga to the whole of the region fabric. It confirmed only partially, because the increase of integration was noticed more in the analyzed set than in the area that interests us, the Jardim Piratininga. In this case, the increase in integration was more circumscribed to the proposed axis, not spreading.

The hypothesis 4, even more radical, proposes a new longitudinal road which, also by its extension, would substantially alter the design of the Jardim Piratininga, which has its urban form, currently, by the circumvallation stream (Figure 6). It should be said that this stream defines a border between the Municipality and the State, since it defines the limit to an area of the Tietê Ecological Park. However, such a stream, whose sinuous design is a specter of the meanders of the old times Tietê River (Claro et al, 2016), far from integrating the whole of the park, is rather a frank and anachronistic barrier that stops the urban occupation that occurs there.

What Hypothesis 4 offers us is the possibility of verifying and demonstrating the advantages of revising an urban design through a radical intervention that would imply reviewing the zoning barriers themselves, not only property,

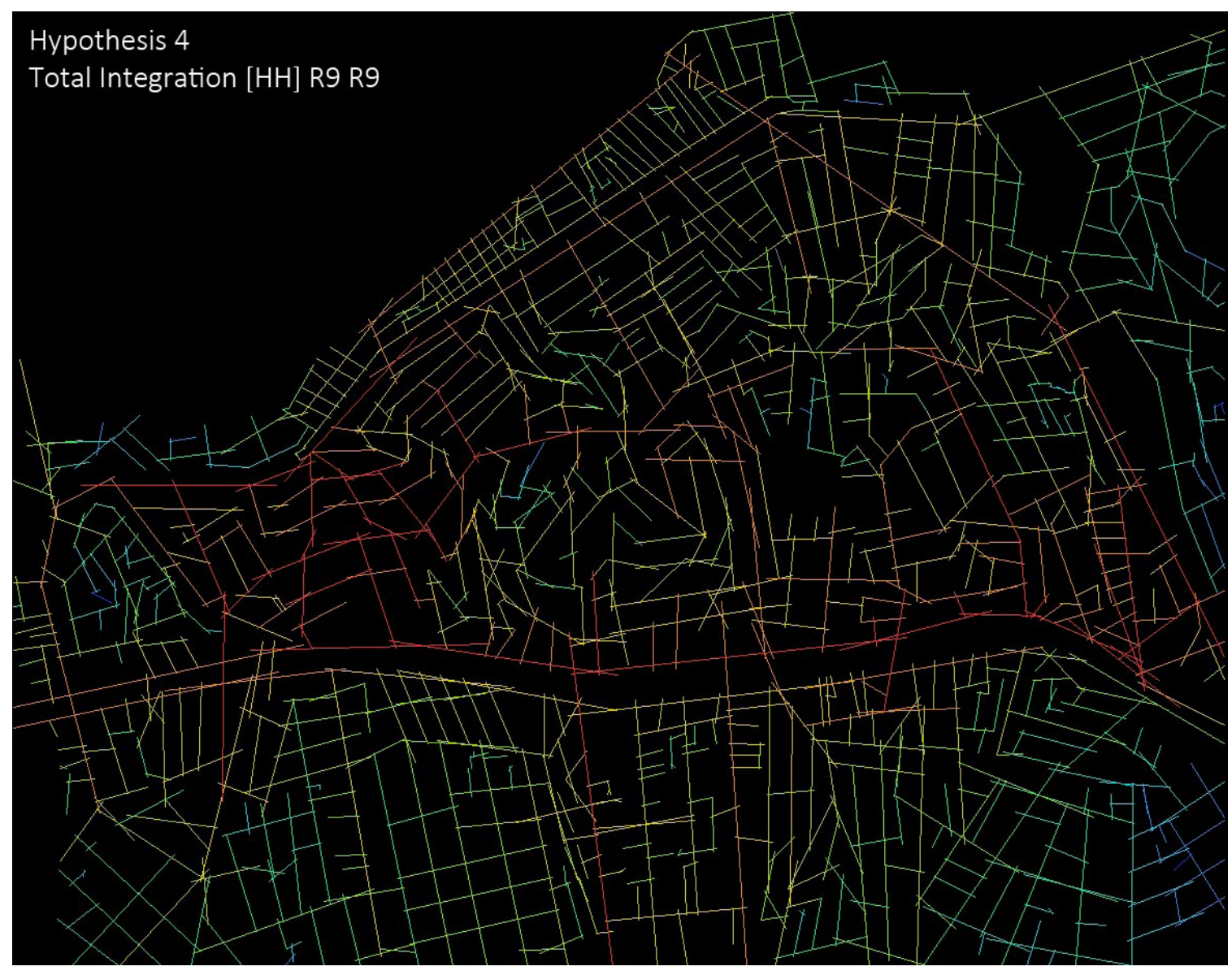

Figure 6. Hypothesis 4: Total Integration [HH] R9 R9 (authors, 2017) 
but land use and responsibility, including environmental parameters. And, among the conditioning barriers, the circumvallation stream, which eventually contracts and dilates the local tissue, is the only urban element that subsists as an anachronism, since the effective barrier that defines the biome of the park itself is the Ayrton Senna Highway. The area circumscribed between this last barrier and the stream is the soccer fields, effectively residual. This is a fundamental issue facing the prerogative of the social function of urban land, also contained in the 2012 Strategic Master Plan, which inevitably comes up against more complex conflicts and problems involving a greater diversity of actors and interests.

\section{Conclusion}

This brief study proves that the application of Space Syntax responds to effective demands related to the territory in question, since it is in course a neighborhood urban plan. It demonstrates that this theory and methodology can offer a variety of available parameters in order to provide subsidies to the plan development.. Certainly the material produced and knowledge acquired will be able to serve this work, fueling other concerns and subsidizing the analysis of other eventual hypotheses. We believe that this is the main contribution of this study so far, and we have good expectations of its future developments, since only the first battery of tests was carried out, stimulating new approaches and propositions.

The space syntax tool proved to be valuable in demonstrating the current condition of the place as a fruit not only of its borderline constraints but, above all, of its insertion in a larger context. The exercise made clear what should be the content of the necessary interventions in order to effectively transform a idiorrhythmic conglomerate with the characteristics of Jardim Piratininga: a stratum of a little porous and accessible urban fabric, very cloistered and segregated. It has also revealed how the boundary characteristics that condition some specific area can make it peculiar and exceptional, and at the same time problematic and disregarded. Many times, these situations seem to be irremediable or a simple subsistence of an apparently perfectly sanctionable misconception, that would be provided if the appropriate measures were taken, even if they are radical ones.

\section{Notes}

${ }^{1}$ Term used as Coelho (2013)

\section{References}

Claro, M., Calvo A., Saito A. and Zylbersztajn, B. (2016) Plano de Bairro no Jardim Piratininga (Penha, São Paulo): desenho urbano e participatividade à luz do Plano Diretor Estratégico (Anais da IV Conferência de Planeamento Regional e Urbano, Universidade de Aveiro).

Coelho, C. (2013). Os Elementos Urbanos (Argumentum, Lisboa).

Cunningham, D. (2005) The Concept of Metropolis. Philosophy and Urban Form (Radical Philosophy 133, 13-25).

Hillier, B. (1996) Space is the machine (Cambridge University Press, Cambridge).

Hillier, B. and Leaman, A. (1976) Space syntax (Environment and Planning B: Planning and Design 3, 147-185).

Medeiros, V. (2006) Urbis Brasiliae Ou Sobre cidades do Brasil. Inserindo assentamentos urbanos do país em investigações configuracionais comparativas (Tese de doutorado, Universidade de Brasília).

Oliveira, V. and Correia, C. (eds.) (2015) Diferentes abordagens no estudo da forma urbana (Faculdade de Engenharia da Universidade do Porto Edições, Rede Lusófona de Morfologia Urbana).

Viana, D. (2015) [Auto]organização e forma urbana. Combinando diferentes abordagens morfológicas na análise de Maputo (Faculdade de Engenharia da Universidade do Porto Edições).

Viganò, Paola (2006). Prototypes of idiorrhythmical conglomerates and shared spaces (Officina Edizioni, Milan). 